\title{
Geo-economics and the Hub and Spokes system: the Japanese case
}

Geoeconomia e o sistema Hub and Spokes: o caso japonês

La Geoeconomía y el sistema eje-rayos: el caso japonés

Ricardo Vega'

DOI: 10.5752/P.2317-773X.2021v9.n3.p33

1. $\mathrm{PhD}$ in Economic Science. Professor at Universidad Tecnológica de México - UNITEC MÉXICO - Campus Ecatepec. Contact: ricardo_vegap@my.unitec. edu.mx.

Recebido em: 01 de junho de 2020

Aceito em: 09 de setembro de 2020

\begin{abstract}
This paper examines the reasons why Japan has been building a foreign trade policy based on a hub-and-spokes system. It will be argued that aside of exports promotion, Japan's trade policy needs a broader reconsideration through a geo-economics approach. Geo-economics provides an appropriate framework of study for it considers that economic means have been becoming more relevant to exert power overseas so as to reach political and economic goals altogether. What defines Japan's pursuit of several bilateral trade agreements is assuring its relative economic hegemony whilst changes in the world balance of power are taking place. In order to achieve so, Japan uses its economic power to promote its interests through a comprehensive trade strategy. In this sense, Japan strategically pursues geo-economic goals since it faces an uncertain and unforeseeable future, and it needs to strengthen its trade policy to guarantee access to international markets as well as pursuing geo-economic goals through its hub-and-spokes.
\end{abstract}

Keywords: Japan. Geo-economics. Hub and spokes. Bilateralism. International trade.

\section{RESUMO 2}

Este artigo examina as razões pelas quais o Japão vem construindo uma política de comércio exterior baseada num sistema hub-and-spokes. Argumentar-se-á que, além da promoção das exportações, a política comercial do Japão precisa de uma reconsideração mais ampla por meio de uma abordagem geo-econômica. A geoeconomia oferece um adequado arcabouço de estudo, pois considera que os meios econômicos têm se tornado mais relevantes para o exercício de poder no estrangeiro de forma a atingir conjuntamente os objetivos políticos e econômicos. O que define a busca do Japão por vários acordos comerciais bilaterais é o asseguramento de sua relativa hegemonia econômica enquanto ocorrem mudanças na balança de poder mundial. Para tanto, o Japão usa seu poder econômico para promover seus interesses por meio de uma estratégia comercial abrangente. Nesse sentido, o Japão busca estrategicamente objetivos geoeconômicos, visto que enfrenta um futuro incerto e imprevisível e precisa fortalecer

2. Translated by Cláudio Augusto Ferreira. Doctoral student in Media and Audiovisual Processes at University of São Paulo. E-mail: claudio.ferreira@usp.br. 
3. The Ministry of Foreign Affairs of Japan refers to its trade agreements as FTA and EPA (Economic Partnership Agreement). EPA's incorporate several kinds of economic cooperation between Japan and each of its partners, aside of sheer trade liberalisation. For purposes of this paper, FTA will be used to refe to those agreements signed by Japan,

in which tariffs and regulations on services sector have been reduced or eliminated, business environment has been improved and intellectual property protection rules have been enhanced all characteristics are found in all FTAs listed in this paper. Source: Ministry of Foreign Affairs of Japan. sua política comercial para garantir o acesso aos mercados internacionais bem como perseguir objetivos geoeconômicos por meio de seus hub-and-spokes.

Palavras-chave: Japão. Geoeconomia. Hub and spokes. Bilateralismo. Comércio internacional.

\section{RESUMEN}

Este trabajo tiene por objetivo examinar las razones por las que Japón ha estado construyendo una política de comercio exterior basada en un modelo eje rayos. Se argumentará que además de la promoción de exportaciones, requiere una reconsideración mediante un enfoque geoeconómico. La geoeconomía permite establecer un buen marco de análisis debido a que su cuerpo teórico propone que los medios económicos son más relevantes para ejercer poder en el exterior con el propósito de alcanzar objetivos tanto de naturaleza política como económica. Japón se ha dedicado a firmar varios acuerdos bilaterales en los últimos años, pero la promoción de exportaciones no es el principal componente de esta estrategia. Por el contrario, lo que define la firma de acuerdos bilaterales por parte de Japón es asegurar su hegemonía económica relativa en el medio de cambios que están ocurriendo en el balance de poder mundial. Mientras Japón enfrenta un futuro incierto e impredecible, se ve obligado a reforzar su política comercial para garantizar el acceso a los mercados internacionales, así como la persecución de objetivos geoeconómicos a través de acuerdos bilaterales en un sistema eje-rayos.

Palabras clave: Japón. Geoeconomía. Eje-rayos. Bilateralismo. Comercio internacional.

$$
\text { Introduction }
$$

Japan has put into action a vast array of free trade agreements (FTAs) in the last twenty years. However, Japan, since the end of WWII and well into the nineties, had been reluctant to sign trade agreements, mostly due to the far-reaching political leverage of rural elites inside the Liberal Democratic Party (LDP) dominance. Whilst the US had already negotiated and agreed NAFTA and the European Single Market has already been in place as early as 1993, Japan engaged in its first FTA negotiations with Singapore and reached an agreement in 2004, and few months later, it signed a new FTA with Mexico. In subsequent years, Japan has put a total of 16 bilateral FTAs in effect with countries and regions from four different continents. ${ }^{3}$

This new appetite for trade agreements prompts a discussion on the underlying reasons why Japan has engaged into pushing ahead such a trade agenda. This paper will single out that the purpose of putting several FTAs into effect is aimed at begetting a hub-and-spokes (H\&S) system, capable of safeguarding its economic and political interests in the world economy. The H\&S hypothesis' theory supposes a (hub) country that decides to sign two (or more) FTAs with two different (spokes) countries, but there is no FTA signed between those spokes.

It will be argued that the Japanese government has set up a H\&S, attempting to hold the hub position and make the most of each FTA, in order to ensure its relative economic hegemony. Given the new world changes in the last twenty years, Japan needs to maintain its economic 
dominance over its regional and global production networks by enhancing its trade policy as well as international political and geo-economic goals through several FTAs. The Japanese H\&S system goes beyond increasing exports alone, and a geo-economic approach could contribute to elucidate that Japan pursues goals that entail protecting its production networks, maintaining a competitive export sector, securing access to energy supplies, supporting liberal values and containing the Chinese influence in the Asian region.

The first section will make a brief appraisal of the main H\&S contributions. An important debate is the efficiency of a H\&S economic integration vis-à-vis a free trade area, wherein leading discussions have put their attention to the effects caused by an H\&S integration to the hub and to spoke countries. Afterwards, a geo-economics approach will be introduced in order to explain the Japanese H\&S integration system, as well as preferences, interests and goals pursued. Finally, it will be possible to affirm that Japan's trade policy rationality goes beyond increasing exports. Instead, Japan has pursuit geo-economic objectives through every FTA signed.

The hub-and-spokes hypothesis

Wonnacott (1975) proposed a two-sided triangle trade integration model by considering that the globalisation process was fragmenting into regional blocs and how this could disrupt global trade ${ }^{4}$ . In order to compensate that situation, he suggested, Canada should sign two different trade agreements, one with the US and another with the Single European Market, creating a two-sided and overlapping trade area with Canada at its centre. He supposed that his overlapped two-sided triangle would benefit Canada by enjoying a preferential access to each market and make the most from the global fragmenting process (WONNACOTT, 1975, p. 6-8).

\section{Figure 1. Hub-and-spokes diagram}

\section{Spoke A}

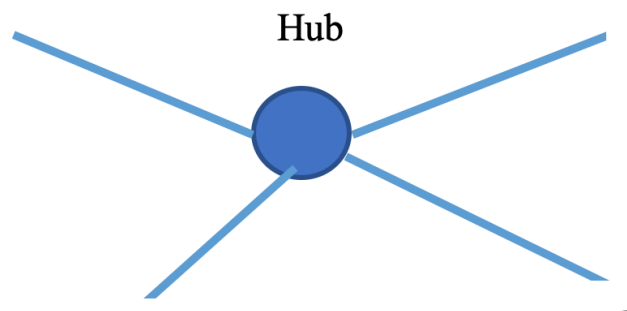

Spoke B

Spoke D
Spoke C

\section{Source: own elaboration based on Wonnacott's diagrams.}

Park and Yoo (1989) defined Wonnacott's two-sided triangle as a star. They supposed cases in which the core (hub) country's trade gains could take place in more inexpensive intermediate goods, greater market

4. Part of Wonnacott's diagnosis is that GATT's liberalisation agenda of creating a global free trade zone has been being replaced by the conformation of economic blocs that would actually stifle international trade by stablishing regional protectionist barriers against outsiders. In his particular study, he considers the situation in which Canada would be left out of any regional bloc. On the one hand, Canada would not be part of the Single European Market project but, on the other hand, a deeper integration to the US economy would cause political and economic upheavals in Canadian politics. 
1. Their data comprises time series of 96 countries covering the period of $1960-2000$ access, replacement of imports and how differentiation between two similar national economies could only take place by tariffs, a situation that would be beneficial for the core country. Lipsey (1990) later named Wonnacott's two-sided triangle and Park and Yoo's star as hub-and-spokes as depicted in figure one.

A H\&S system consists of a (hub) country that decides to sign two (or more) bilateral agreements with two or more (spokes) countries. The hub country will hold a central position since all economies are linked to it by bilateral agreements. The spokes countries are incorporated into the $\mathrm{H} \& \mathrm{~S}$ system once a bilateral agreement is signed. As Figure 1 depicts, a H\&S does not create a free trade zone since spokes countries do not enjoy preferential access to all markets. In fact, spokes face discrimination since there are not trade agreements signed amongst them. A H\&S integration system is more complex than sheer bilateralism since economic integration is designed by the hub country, which strategically decides to sign several bilateral agreements in order to hold a central position to shape economic integration. In other words, a H\&S system is formed by several bilateral FTAs that links the hub country to other national economies, in which it retains a central position within this form of economic integration.

Lipsey (1990) proposed his H\&S theory as an alternative to a plurilateral regionalism or a free trade area in the North American integration process. Lipsey's discussion revolves around what a country could either win or lose if embarked upon a H\&S integration path in comparison to a free trade area. His reckonings consider that each model of integration brings about different outcomes in trade gains and economic dominance. Subsequent debates picked up on the H\&S efficiency, using sundry economic variables of study, econometric models and single country cases.

Wonnacott (1996) has argued that the hub tends to increase its welfare in both situations, a free trade area or a H\&S area because in both cases the hub enjoys preferential access to all markets. Hur, Alba and Park (2010) estimated that a hub could increase its exports quota by $5.57 \%$ per year and doubles after 12 years ${ }^{1}$. Similarly, they affirm that spokes are able to increase its exports as well. Mukunoki and Tachi (2006) explore the possibility of achieving greater trade liberalisation through a H\&S system due to the associated flexibility in setting trade policy in comparison to a free trade area. Therefore, their study concludes that a H\&S system provides more solid ground to achieve trade liberalisation.

However, a recurring conclusion in H\&S literature is that a larger portion of trade benefits and efficiency are achieved by the hub alone. Yildiz (2014) uses an oligopoly model of trade and assumes that the hub is more efficient than spokes, which under such conditions the hub benefits at the expense of the spokes. The author argues that the hub's preferential access to markets improves world welfare because it helps allocate resources more efficiently and, therefore, it could gain more from a H\&S system than a free trade area; nonetheless, an inefficient spoke ends worse off. Das and Andriamananjara (2006) also conclude that a H\&S system disproportionally benefits the hub in comparison to spokes since the former becomes more advantageous to export to spokes' markets than 
spokes exporting to the hub market. Wonnacott (1996) explains what incentives the hub has within a H\&S at spokes' expense. For instance, if the hub is a large economy, such as the US, it would benefit more based on its volume of trade and preferred locations because it has the possibility of enlarging its dominant role through a trading structure that sets its preferences. Wonnacott and Kowalczyk (1992) emphasize the possibility of a hub, which holds specific economic advantages, to set its preferences when building a H\&S system. Thus, comparative advantage and economies of scale work positively to build a H\&S system, which is more favourable to the hub (WONNACOTT, 1991, p. 34).

Other works underscore the hub status for different types of countries. For instance, Mukunoki and Tachi (2006) modelled a situation in which small economies (i.e. Singapore) prefers to be a hub in the middle of two big economies (US and Japan) as spokes. Their study suggests that pursuing a hub status is also advantageous for small economies. Deltas, Desmet and Facchini (2012) discuss Israel's case as the only country to have an FTA with the US and the EU. Israel's bilateral trade with both economies increased when both agreements were signed and benefited at the spokes' expense. De Benedictis, De Santis and Vicarelli (2005) conclude that small economies orbiting around the EU15 and other European trade blocks report them more trade gains. Therefore, it is demonstrated in several works that pursuing a hub status within a H\&S is determinant for a country to sign more FTAs because it reaffirms its hub position and its corresponding gains (CAO, 2015).

Nevertheless, spokes do not attain comparable benefits. Whereas the hub increases its exports, spokes lose. Hub firms could buy inputs from spokes and could increase their exports share into the spokes' markets; spokes, on the other hand, get less rich specially if separate FTAs substitute trade (WONNACOTT, 1996, p. 241). Thus, as the hub adds new spokes to its H\&S system, each substitute agreement will hurt an existing spoke because of trade deviation effect. Wonnacott and Kowalczyk (1992) suggest that a trade paradox arises to spokes: a spoke country loses when the hub expands its H\&S system by signing another FTA, but the aforementioned spoke will still have incentives to remain in the integration process because the spoke will prefer to be part of a H\&S since it provides benefits in the long run than being left out of any trading bloc (LIPSEY, 1990; WONNACOTT, 1996).

A different portion of literature upholds that hub countries gains are limited or, in some cases, absent. Horaguchi (2007) affirms that trade diversion is an effect caused by an accumulation of FTAs by a single hub which could cause overproduction and turmoil in regional economies ${ }^{2}$. Lloyd and Maclaren (2004), and De la Reza (2014) point out the problem of facing different rules of origin (ROOs) in a H\&S system, which may lead to administrative costs related to verification. Lee, Park and Shin (2008) concluded the same argument on overlapping FTAs and the costs involved to administrate different ROOs to identical products traded in different countries ${ }^{3}$. Nonetheless, Hayakawa and Matsuura (2017) affirm the opposite in the case of Japanese affiliates in Southeast Asia when complying with ROOs since there are high shares of originating inputs. In
2. Spaghetti Bowl effect and trade diversion are effects attributable to not well-connected markets (HORAGUCHI, 2007) since spokes markets are differentiated by multiple rules of origin. As Horaguchi (2007) demonstrates through an equilibrium model, such conditions alter production decisions leading to overproduction.

3. An effect commonly known as spaghetti or noodles bowl caused by signing several trade agreements, which forces companies to administrate many R00s when exporting to different markets, causing additional costs to exporters. 
summary, the H\&S supposes cost raises due to tariffs differentiation stipulated on each FTA which would force companies to hire specialised human resources in order to get the best benefits of all FTAs (WONNACOTT; KOWALCZYK, 1992, p. 18). Therefore, bilateral FTAs, which build up a H\&S system have a small impact on welfare and employment (BROWN et al, 2006).

All these works acknowledge that a H\&S either results in a greater benefit for the hub and loses for spokes or they definitely argue that there are no trade gains whatsoever. Its efficiency over free trade areas is debatable and it depends on which variables, circumstances, assumptions and time series are analysed. Then, a relevant question to ask at this point would be why Japan is constructing a H\&S system. In order to answer that enquiry, it is necessary to understand Japan's geo-economic goals pursued in each FTA. Such goals may not necessarily result in greater export quotas, but other benefits of geo-economic nature are gained as it will be discussed in the following pages.

The Japanese Hub-and-spokes system

The post-war Japanese economic miracle narrative embedded a state-led industrial policy which focused on extensive capital goods investment, industrial promotion and a technology catch-up strategy. This, in turn, underpinned an export-led growth, in which the US - Japan alliance provided a stable framework of access to international markets to obtain natural resources for industrialisation as well as outstanding revenues from exports. The high-growth era $(1955-1971)$ provided a stable outgoing flows of Foreign Direct Investment (FDI) and Official Development Assistance (ODA), which permitted Japan to exert a growing influence globally (STUBBS, 2001; HATCH, 2002). ODA and FDI were important engines of the Japanese economic foreign policy in the post-war era (HATCH; YAMAMURA, 1996). Both enabled Japan to start the construction of its production networks all over the region as it exported labour intensive production processes overseas. The export-oriented infrastructure in developing countries contributed to the development and enhancing of the Japanese regional industrial project since the late 70s. As a result, the Japanese industrialisation success turned it into a dominant exporter of high value-added goods, specially automobiles and electronics.

Nevertheless, the last two decades of the $20^{\text {th }}$ century beheld Japan's boom and decline of its economic model. Japan now faces a distinct and unforeseeable economic future. This has thrusted Japan to rethink policies that two or three decades ago would have been unlikely. As international conditions changed, Japan's ability to fuel its own economic interests are no longer supported by neither a robust economic growth nor a US-led global economy. Furthermore, the $21^{\text {st }}$ century started witnessing how the last WTO's round of negotiations, the Doha round, has derailed, struggling with a poorly defined agenda. Ambiguities on manufacturing sectors of developing nations and agricultural subsidies of developed countries have been amongst the most important barriers to 
continue negotiations (HANS VAN MEIJL et al, 2005; AKYÜZ et al, 2006; GALLAGHER, 2008).

Besides, the regionalisation processes that have been taking place in Europe and North America, the lasting consequences of the 1997-98 Asian financial crisis and the 2008-2009 Great Recession foisted more obstacles to multilateral cooperation (KAWAI; WIGNARAJA, 2013). As a result of that international environment, several countries have started to promote their economic interests individually and it has given way to a new path of global economic integration through bilateralism ${ }^{4}$. Specifically, Japan has decided to build a H\&S system by signing sundry bilateral FTAs.

As shown in Figure 2 below, by the end of 2018, Japan has 16 FTAs in effect, following a H\&S system where it holds the hub position. Exports have increased to certain markets since each corresponding FTA became effective; however, not all accords have resulted in positive numbers for Japan. If Japan had pursued an agenda based on exports promotion solely, a free trade area would have been preferred; instead, a H\&S was favoured. Japan, aside of augmenting its chances to increase exports, it is also pursuing other motives of geo-economic nature.

Figure 2. FTAs signed by Japan

\begin{tabular}{|l|l|l|l|}
\hline Partner & Effective date & Partner & Effective date \\
\hline Singapore & 2004 & Brunei & 2010 \\
\hline Mexico & 2005 & ASEAN & 2010 \\
\hline Chile & 2007 & Switzerland & 2010 \\
\hline Malaysia & 2007 & India & 2011 \\
\hline Indonesia & 2008 & Peru & 2011 \\
\hline Philippines & 2009 & Australia & 2015 \\
\hline Thailand & 2009 & Mongolia & 2016 \\
\hline Vietnam & 2009 & European Union & 2018 \\
\hline
\end{tabular}

Source: own elaboration from Ministry of Foreign Affairs of Japan.

The Geo-economic proposition

Luttwak (1990) introduced the term geo-economics as a new form of statecraft in which economic means of power are more relevant than military ones. His thesis proposes that given the end of the Cold War, the importance of economic power has surpassed military power and traditional geopolitics as means to influence and exert control over other nations. Scholvin and Wigell (2018) define geo-economics as a "foreign policy strategy which refers to the application of economic means of power by states so as to realize strategic objectives" (SCHOLVIN; WIGELL, 2018 , p. 80). In other words, geo-economics deals with economic bases of power and how economic instruments to exert power. They see geo-economics as an extension of geopolitics because its logic entails interstate rivalry and superiority over others as the ultimate end, which emphasizes
4. Other forms of regional and transcontinental integration have been proposed as a form of deepening trade integration due to the Doha Round paralysis, such as Trans Pacific Partnership (TPP), RCEP (Regional Comprehensive Economic Partnership), or CPTPP (Comprehensive Agreement for Trans-Pacific Partnership). 
how competition for relative power drives state demeanour (SCHOLVIN; WIGELL, 2018, p. 80-81).

Kim (2019) defines geo-economics as "state's foreign economic policy to promote and defend mid- and long-term strategic interests". Any foreign trade, finance, investment, and industrial policy can be considered geo-economic instruments as long as they are deliberately designed and implemented to attain strategic objectives (KIM, 2019, p. 155). He presupposes that state relations orbit around a condition of vulnerability and interdependence. States implementing geo-economic strategies try to create and exploit this condition in its relations with other states in order to induce desired strategic outcomes.

Geo-economics' main goal is directly aimed at the accumulation of wealth through market control (COWEN; SMITH, 2009). Its means are market-based instruments to assert power and influence. For instance, a country could try to bend trade flows, capital and knowhow into its advantage (HOLSLAG, 2015); or a state could widen exports as a geo-economic strategy as it expands the country's wealth and this becomes an attempt to limit economic vulnerability. Geo-economic stratagems are also capable to shape how businessman behave in order to adapt to restrictions and opportunities provided by the state economic policy (CALVO, 2018). Nonetheless, it must also be acknowledged that all economic measures for geo-economics work by politically distorting economic conditions and inadvertently, constrain free economic transactions of domestic firms and individuals (KIM, 2019, p. 160).

Furthermore, as Japan pursues greater welfare through trade liberalisation, it can also determine its own scope to set rules that are favourable to its political goals. Pekkanen, Solis and Katada (2007) propose that Japan trades off between two facets: control and gains in international trade. On the one hand, they distinguish that Japan favours liberalisation through international forums, whose rules promise economic gains to those who participate. On the other hand, as states participate in specific negotiations, they also compete to exert control over the liberalisation agenda in trade talks. Thence, it is possible to "maximise gains from trade as industrialised nations must negotiate with large trading partners, or with numerous smaller countries that agree to enact common trade and investment rules" (PEKKANEN et al, 2007, p. 956).

In their view, Japan signs trade agreements that augments Japan's control to set rules that effects its business and political interests, whether it means to augment its exports or not, but Japan could get more control over the economic integration process. A hub-and-spokes bilateralism endorses Japan to choose and set its preferences, values and pace of trade and investment liberalisation, according to its geo-economic stakes in order to maintain its economic relative hegemony. In order to assert its economic supremacy, for the first time, the Japanese political elite weighed the possibility of signing trade agreements and embarked in its first FTA negotiations to guarantee its economic dominance in two regions relevant to Japanese interests: Southeast Asia and North America. Thus, Japan sought to sign an FTA with Singapore and Mexico, respectively.

As mentioned before, Japan's rural elites exerted a vast influence to block any attempt to sign trade agreements. However, key FTAs suppor- 
ters commenced to push a different trade agenda. Transnational Japanese firms with vertically-integrated and regionally-fragmented operations, that had been moving labour-intensive stages of production into developing countries since the 70 s, are a sensitive group of companies interested in pushing trade liberalisation because its operations became more efficient regionally, allowing them to re-export to other markets (MANGER, 2005, p. 810). In order to deepen economic integration and make the most of these regional networks, such industries organised around the industrial Keidanren Group ${ }^{5}$ to concert a lobbying effort to advance their economic agenda with the Japanese Diet. Hence, Keidanren directed the evolution of the FTA with Mexico and ASEAN countries in order to maintain and expand their economic interests (YOSHIMATSU, 2007).

The Japan-Singapore FTA focused on economic complementariness, FDI promotion and increase of exports. Furthermore, since China's WTO entry in 2001, the Chinese government expressed its interest in achieving an FTA with ASEAN, something that was perceived by Japan as a menace to its own economic interests in the region (WONG; CHAN, 2003; CHENG-CHWEE, 2005). By singing an FTA with Singapore and using it as a pivot to Southeast Asia, Japan has hoped to maintain its hegemonic position in the region. Besides, the FTA with Singapore did not pose a threat to the rural elites and could provide economic benefits to Japanese multinational firms overseas.

In the case of an FTA with Mexico, Japan had interpreted NAFTA as a discriminatory treatment to its exports since American companies could invest and move goods across the border paying no customs duties or other fees (MANGER, 2005, p. 812; KERBER, 2008, p. 353). Hence, as early as 2000 , Keidanren officials had undertaken the first steps to discuss with the Mexican government a possible trade agreement between both countries. The Japan-Mexico FTA meant to Japan an opportunity to get preferential access to the North American region since Japan, as the second largest economy of the planet (of that time), was in clear disadvantage to manufacture in Mexico vis-à-vis its American and European competitors.

Although Mexico seemed to be a more obvious threat to the Japanese agricultural sector, the Japanese government was capable of explaining to its own party members and to the Nokyo lobbying group ${ }^{6}$, who both opposed the agreement, that most Mexican products would not directly compete with Japanese goods (YOSHIMATSU, 2005, p. 270-272; KERBER, 2008, p. 361). As a matter of fact, and contrary to what many opponents of the Japan-Mexico FTA feared, Mexican exports to Japan have not posed any menace to local farmers, nor even have they grown as the Mexican government initially had expected.?

In both cases, the Japanese government was capable of setting its preferences when negotiating both FTAs. The Japan-Singapore FTA worked as path towards deeper integration to the ASEAN region as a way to respond to China's involvement in Southeast Asia. In the case of Mexico, Japan attained access to its low-cost labour force and strengthened its operation in a geographical proximity to the US market. In other words, Japan pushed its geo-economic interests and used tactical means to set its
5. It is an economic organisation with a membership comprised of 1,444 representative companies of Japan, 109 nationwide industrial associations and the regional economic organizations.

6. It is a lobbying group that represents all agricultural unions and cooperatives of Japan.

7. Japanese opposers to the Japan-Mexico FTA believed that Mexican products would affect local farmers; however, main agricultural products exported by Mexico such as pig-meat, beef and some vegetables and not produced in Japan. Once, such belief was overcome, the agreement cemented more support in Japan. 
8. The Japan-Malaysia FTA was finally realised by Japan after several attempts to deal with post-Mohammad administrations (1974 - 2004) and build stronger economic relations. Najib's administration (2009 - 2018), particularly, tried to get closer to China (MD. KHALID, 2011);

a situation that Japan perceived as a threat to its interests in Malaysia, which has been a good destination for investment and a potential link for enhancing relations with other ASEAN nations.

9. A year after Malaysia's FTA was completed, Japan signed an FTA with Indonesia, where Japan has vast interests as it is Indonesia's biggest donor and main foreign investor. Japan's presence and interests in Indonesia affords Japan a great opportunity to influence the democratisation of Indonesia (PURBA, 2001, p. 55).

10. Thailand looked for closer integration as a result of China's entry to WTO and Doha's failure (CHIRATHIVAT; MALLIKAMAS, 2004), and has viewed bilateral trade liberalisation as mutually reinforcing, especially with Japan because its trade and exports structure is already well established

(TALERNGSRI; VONKHORPORN, 2005).

11. Vietnam's growing role in ASEAN and the region has increasingly attrac-

ted Japan's attention. The Japanese government saw Vietnam as a potentia player in the East Asian regional politics. The Japanese government has sought another foundation of economic integration with the ASEAN region so as to retain its dominant economic powe in Southeast; and so, the Japan-Vietnam FTA contributes to regional peace and security and helps increase the East Asia integration process (LUONG, 2009)

12. Japan was capable to sell an FTA to the Filipino government as matter of security due to China's more assertive stance in the South China Sea (VAN DE HAAR, 2011, p. 121). At the same

time, the agreement was promoted within specific business groups in the Philippines as the best chance to create wealth from liberalised trade.

13. China's involvement in ASEAN has resulted in several geopolitical manoeuvres by all parties: Chinese military bases in the South China Sea, maritime disputes over territorial waters and Chinese FDI to several ASEAN members Japan, in order to dilute China's in-

fluence, approach each ASEAN country, so its economic agenda is negotiated individually. This way, Japan could sell (or share) to each nation the perception

of China as a threat and build a joint front to oppose China's influence. foreign policy to tie its economy to other countries in order to gain strategic leverage. At this point, it is conceivable to realise that geo-economics has become highly relevant for Japan since its tactical practice has enabled Japan to increase interdependence on its own advantage

In fact, these two FTA negotiation experiences paved the path for Japan to negotiate subsequent FTAs. Solis and Katada (2007), for instance, affirm that the whole negotiation process with Mexico helped Japanese companies and government bureaucrats acquire 'FTA knowhow'. From a geo-economic perspective, both agreements (with Singapore and Mexico) worked as means to support targeted industries and build stronger capabilities to export in greater amounts, with a focus on high-value-added segments of production networks with both regions (SCHOLVIN; WIGELL, 2018). Although, this strategy might represent a loss to Japanese farmers, Japan ultimately did it in order to uphold its dominant position in key industries such as automobiles and electronics of two significant economic regions, Southeast Asia and North America.

The subsequent FTAs agreed by the Japanese government with its Asian neighbours responded to the Japanese objective of protecting its geo-economic interests. Between 2007 and 2010, Japan signed FTAs with most of ASEAN countries. In all cases, Malaysia ${ }^{8}$, Indonesia ${ }^{9}$, Thailand ${ }^{10}$, Vietnam $^{11}$ and Philippines ${ }^{12}$ have long standing economic interests with Japan, such as FDI and ODA flows, cross-border production networks and several infrastructure projects funded by the Japanese government. Japan and all ASEAN partners have come to perceive that bilateral FTAs benefits would strengthen strategic cooperation as well as enhancing their economic bonds. In turn, this could lead to a commitment in maintaining peace and stability amongst them (SEN; SRIVASTAVA, 2009). Furthermore, when the China-ASEAN FTA was reached in 2010, Japan was pressured to deepen its economic ties in Southeast Asia. ${ }^{13}$

FTAs outside the Asian region

Japan's geo-economic interests stand beyond the ASEAN region. For that purpose, Japan has signed several trade agreements to either protect or expand its interests in other parts of the world, specifically with India, Australia and Europe. India and Japan used their mutual interests to push a deeper economic relation. Since the late 80 s, India' manufacturing industry entered an export-led growth era and started to attract greater amounts of Japanese FDI that contributed to expand Japanese firms' businesses in the country. Thus, India turned into a strategic objective of Japan's diplomacy and, consequently, completed an assistance plan for India in 2006 that would focus on three areas: promoting economic growth, addressing poverty and environmental issues and supporting the expansion of human resource development (SATO, 2012).

Japan's closer relation with India responded to the Japanese government's perception that there are trade and services complementarities between Japan and India (SATO, 2012; GAURAV; BHARTI, 2018), and thus, FTA negotiations were completed and came into effect in 2011. Japan set its preferences with India by removing all obstacles to Japanese 
investments, setting strong investment protection provisions and technology transfer is not compulsory for investor (SENGUPTA, 2011). As previous FTAs experiences, Japan reserved agricultural products on its exclusion list in order to protect its political and economic interests with its rural elites.

By the same token, the FTA with India entailed geo-economics goals as well. The China menace and the US involvement in Asia pushed Japan to build stronger ties with India. Strategically, a quadrilateral framework involving Japan, India, the US and Australia built an alliance of democracies described as the 'arc of freedom and prosperity' to contain China (JAIN, 2010, p. 409). In this matter, the Japan-India strategic partnership counterbalances China's influence, which must be a long-term goal as both countries are more dependant to the prosperity of Asia-Pacific (SEKI, 2000).

Australia, likewise Japan, perceives China as a threat. So, the role of a bilateral partnership between Japan and Australia, both key regional US allies, was meant to counter the emergence of China (TERADA, 2007). An FTA with Australia has been also seen as a complementary trade relation since Japan's major exports to Australia are manufactured goods such as automobiles, auto-parts, machinery, and consumer electronics. Australia's exports to Japan are primary goods such as energy resources, raw materials, and agricultural products.

In Europe, Japan pursued geo-economic objectives as well. On the one hand, Europe has been perceived as a source of inward direct investment and as an important exports market. On the other hand, an FTA could reinforce Japan's global strategy through cooperation with European countries (YOSHIMATSU; ZILTENER, 2010, p. 1073). As a result, Japan has signed two FTAs, one with Switzerland (2010) and, more recently, with the EU (2018). The Japan-Switzerland FTA became a relevant entry door to Japanese investments and to the European market; harmless to Japanese agricultural interest groups.

Japan signed an FTA with the EU particularly pressured by the Korean-UE FTA and the strategic relationship that China could bridge with EU through the One Belt, One Road Initiative. With this brand-new Japan-EU FTA, Japan gets the possibility to influence the EU leaders to avoid a deeper strategic relation between Europe and China that could make Japan invisible in EU's agenda (SODERBERG, 2012). In a globally fragile security environment, Japan and the EU are endorsing each other as reliable partners with shared values, gaining from a joint commitment to preserve the rule-based, liberal world order, supported by ever closer economic integration (FRENKEL; WALTER, 2017). Furthermore, Japan's automotive, electrical engineering, electronics, mechanical engineering and fine chemical industries can expect greater exports to the EU as the FTA would result in a $0.86 \%$ GDP annual growth for Japan in the immediate years when the FTA comes into effect (BENZ; YALCIN, 2015).

Lastly, Japan has signed minor FTA's with less relevant partners, in terms of Japanese trade. Chile, Peru and Mongolia are seen as peripheral commodity suppliers of Asia-Pacific's value chains (DINGEMANS, 2014). 
Japan's main foreign policy towards these countries is securing access to raw materials, promoting overseas business affiliates and increasing exports such as automobiles and electronics (BERRIOS, 2005). Despite these trade agreements may seem irrelevant to Japanese trade, all parties have entered liberalisation policies which have led them to open-up its markets through bilateral and regional initiatives and they could contribute to expand Japanese exports. Japan has simply taken their chances over shared economic agendas with as many countries as possible. In that way, and even if trade benefits are not so significative, Japan has the possibility to resolve diplomatic, security and trade interests (KAWASHIMA, 2017).

Japanese gains and its $\mathrm{H} \& S$

Throughout the H\&S theory reviewed, trade benefits depend on several variables and assumptions which do not necessarily mean positive results. In the case of Japan, each FTA has resulted in varied outcomes, in terms of exports. Japan possesses advantages that could theoretically support the objective of creating a H\&S area. On the one hand, Japan is a large economy that has been signing FTAs with minor economies, which, in turn, provides more possibilities to export more high-value added goods. As shown in Figure 3, main Japanese exports are high-value-added goods: automobiles, electronics, mechanical equipment, etc., which comprise about $70 \%$ of its total exports. These industries were built since the high-growth era, when Japan created a space of economic complementarities with its Asian neighbours. Through shared infrastructure, Japan has eliminated barriers to trade and investment in the region. The Japanese H\&S system has reaffirmed its economic and technological advantage as it gets a larger market share and therefore, more control over high-value -added goods, safeguarding and deepening such interests created since then.

\section{Figure 3. Main japanese Exports in 2018}

87 Automobiles and parts and accessories the reof

- 84 Machinery, mechanical appliances, etc.

= 85 Electric al equipment, sound recorders, tv, etc.

99 Commodities not elsewhere specified

- 90 Optical, photographic, and other precision equipment

- 72 Iron and steel

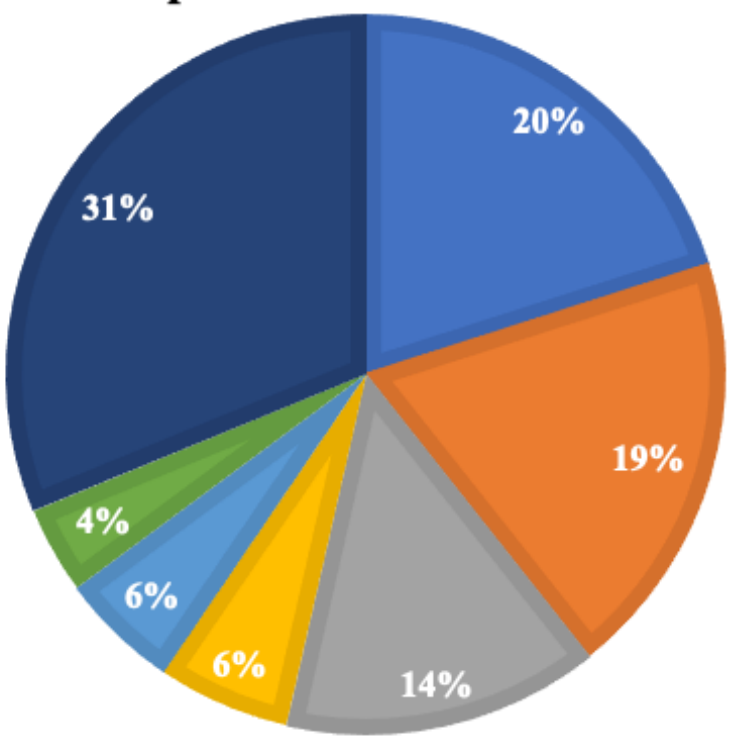

-Others

Source: ITC statistics. Data is organised by Harmonised System (HS). 
Exports to countries with whom Japan has signed FTAs are dominated by these economic sectors (automobiles, electronics, and so on) even before Japan started signing FTAs. However, as some H\&S theorists propose, trade has not really improved Japanese exports in all cases. Japan's FTAs with Malaysia, Thailand and Indonesia do not have a positive impact on Japan's trade due to assorted factors such as a lack of knowledge of FTAs by traders, high costs of using FTAs and difficulties to obtain certificates of origin (ANDO; URATA, 2015). More specifically, Rahman, Molla and Murad (2008) reveal that the Japan-Malaysia FTA has had no effect on trade benefits for any country, confirming the hypothesis of limited trade benefits of H\&S integration.

Figure 4 displays the destination of main Japanese exports; it can be realised that most FTAs represent a small cut for all of its exports. For instance, countries outside the ASEAN and EU28 regions barely absorb $9 \%$ of relevant Japanese exports. As a matter of fact, on an aggregate perspective, FTA markets represent $33.2 \%$ for Japanese exports, which is still a smaller proportion than its main markets, the US and China. Even though it is evident that ASEAN and EU28 have been slowly and gradually getting more important for Japanese goods, there is not clear growing trend, and in some cases diminish.

Figure 4. Main Japanese exports per destination, in percentages of total (2005-2019)

\begin{tabular}{|c|c|c|c|c|c|c|c|c|c|c|c|c|c|}
\hline & HS & 2008 & 2009 & 2010 & 2011 & 2012 & 2013 & 2014 & 2015 & 2016 & 2017 & 2018 & 2019 \\
\hline \multirow{4}{*}{ 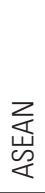 } & 87 & $5.87 \%$ & $7.57 \%$ & $8.13 \%$ & $8.76 \%$ & $10.35 \%$ & $9.14 \%$ & $7.87 \%$ & $7.94 \%$ & $.16 \%$ & $7.79 \%$ & $8.01 \%$ & $7.74 \%$ \\
\hline & 84 & $13.84 \%$ & $14.80 \%$ & $15.67 \%$ & $15.12 \%$ & $18.83 \%$ & $17.20 \%$ & $16.41 \%$ & $16.38 \%$ & $14.94 \%$ & $14.39 \%$ & $14.52 \%$ & $14.30 \%$ \\
\hline & 85 & $16.13 \%$ & $16.32 \%$ & $18.13 \%$ & $17.69 \%$ & $18.82 \%$ & $17.94 \%$ & $18.24 \%$ & $17.62 \%$ & $17.79 \%$ & $18.28 \%$ & $19.37 \%$ & $19.03 \%$ \\
\hline & 90 & $9.79 \%$ & $10.07 \%$ & $11.41 \%$ & $11.59 \%$ & $12.04 \%$ & $11.25 \%$ & $10.74 \%$ & $10.82 \%$ & $11.05 \%$ & $11.35 \%$ & $11.41 \%$ & $11.61 \%$ \\
\hline \multirow{4}{*}{ 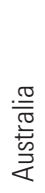 } & 87 & $4.89 \%$ & $6.02 \%$ & $5.86 \%$ & $5.64 \%$ & $6.25 \%$ & $5.57 \%$ & $5.05 \%$ & $4.76 \%$ & $4.76 \%$ & $5.24 \%$ & $5.29 \%$ & $4.62 \%$ \\
\hline & 84 & $1.56 \%$ & $1.63 \%$ & $1.44 \%$ & $1.52 \%$ & $1.66 \%$ & $1.36 \%$ & $1.20 \%$ & $1.16 \%$ & $1.16 \%$ & $1.12 \%$ & $1.18 \%$ & $1.06 \%$ \\
\hline & 85 & $0.78 \%$ & $0.74 \%$ & $0.70 \%$ & $0.63 \%$ & $0.59 \%$ & $0.54 \%$ & $0.42 \%$ & $0.39 \%$ & $0.36 \%$ & $0.36 \%$ & $0.36 \%$ & $0.35 \%$ \\
\hline & 90 & $0.76 \%$ & $0.81 \%$ & $0.67 \%$ & $0.62 \%$ & $0.62 \%$ & $0.68 \%$ & $0.66 \%$ & $0.76 \%$ & $0.71 \%$ & $0.65 \%$ & $0.64 \%$ & $0.60 \%$ \\
\hline \multirow{4}{*}{$\frac{\omega}{\frac{\bar{E}}{\mathrm{~J}}}$} & 87 & $0.69 \%$ & $0.56 \%$ & $0.86 \%$ & $0.70 \%$ & $0.54 \%$ & $0.65 \%$ & $0.51 \%$ & $0.57 \%$ & $0.60 \%$ & $0.65 \%$ & $0.70 \%$ & $0.53 \%$ \\
\hline & 84 & $0.27 \%$ & $0.13 \%$ & $0.18 \%$ & $0.17 \%$ & $0.18 \%$ & $0.12 \%$ & $0.20 \%$ & $0.14 \%$ & $0.10 \%$ & $0.11 \%$ & $0.12 \%$ & $0.10 \%$ \\
\hline & 85 & $0.04 \%$ & $0.05 \%$ & $0.02 \%$ & $0.03 \%$ & $0.04 \%$ & $0.05 \%$ & $0.05 \%$ & $0.02 \%$ & $0.02 \%$ & $0.01 \%$ & $0.01 \%$ & $0.02 \%$ \\
\hline & 90 & $0.07 \%$ & $0.09 \%$ & $0.09 \%$ & $0.12 \%$ & $0.06 \%$ & $0.06 \%$ & $0.06 \%$ & $0.07 \%$ & $0.06 \%$ & $0.05 \%$ & $0.06 \%$ & $0.05 \%$ \\
\hline \multirow{4}{*}{ 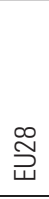 } & 87 & $15.16 \%$ & $14.37 \%$ & $12.68 \%$ & $13.11 \%$ & $9.77 \%$ & $9.43 \%$ & $10.77 \%$ & $11.60 \%$ & $12.51 \%$ & $12.68 \%$ & $12.90 \%$ & $14.61 \%$ \\
\hline & 84 & $18.55 \%$ & $15.71 \%$ & $13.92 \%$ & $14.31 \%$ & 13 & $13.75 \%$ & $14.05 \%$ & $\%$ & $13.51 \%$ & $13.16 \%$ & $13.30 \%$ & $13.28 \%$ \\
\hline & 85 & $15.05 \%$ & $12.38 \%$ & $11.42 \%$ & $11.63 \%$ & $10.66 \%$ & $10.69 \%$ & $10.56 \%$ & $10.01 \%$ & $10.16 \%$ & $9.86 \%$ & $10.26 \%$ & $9.99 \%$ \\
\hline & 90 & $19.84 \%$ & $19.55 \%$ & $17.28 \%$ & $17.02 \%$ & $14.52 \%$ & $14.23 \%$ & $14.61 \%$ & $14.87 \%$ & $15.59 \%$ & $14.66 \%$ & $15.41 \%$ & $16.11 \%$ \\
\hline \multirow{4}{*}{ 䨌 } & 87 & $0.31 \%$ & $0.46 \%$ & $0.51 \%$ & $0.56 \%$ & $0.43 \%$ & $0.36 \%$ & $0.35 \%$ & $0.34 \%$ & $0.35 \%$ & $0.37 \%$ & $0.36 \%$ & $0.29 \%$ \\
\hline & 84 & $1.76 \%$ & $1.67 \%$ & $1.85 \%$ & $2.26 \%$ & $2.26 \%$ & $1.78 \%$ & $1.78 \%$ & $1.75 \%$ & $1.99 \%$ & $1.66 \%$ & $2.07 \%$ & $2.20 \%$ \\
\hline & 85 & $0.79 \%$ & $0.96 \%$ & $0.94 \%$ & $1.07 \%$ & $0.97 \%$ & $0.92 \%$ & $0.80 \%$ & $0.96 \%$ & $1.05 \%$ & $1.01 \%$ & $1.19 \%$ & $1.23 \%$ \\
\hline & 90 & $1.15 \%$ & $1.19 \%$ & $1.18 \%$ & $1.30 \%$ & $1.32 \%$ & $1.21 \%$ & \begin{tabular}{|l|}
$1.12 \%$ \\
\end{tabular} & $1.24 \%$ & $1.38 \%$ & $1.25 \%$ & $1.56 \%$ & $1.62 \%$ \\
\hline \multirow{4}{*}{$\begin{array}{l}\frac{0}{x} \\
\stackrel{0}{x}\end{array}$} & 87 & $1.81 \%$ & $1.86 \%$ & $1.98 \%$ & $2.12 \%$ & $1.95 \%$ & $1.90 \%$ & $2.22 \%$ & $2.52 \%$ & $2.39 \%$ & $2.53 \%$ & $2.29 \%$ & $2.27 \%$ \\
\hline & 84 & $1.02 \%$ & $0.95 \%$ & $0.91 \%$ & $0.89 \%$ & $1.12 \%$ & $1.54 \%$ & $1.73 \%$ & $1.96 \%$ & $1.84 \%$ & $1.87 \%$ & $1.77 \%$ & $1.64 \%$ \\
\hline & 85 & $1.78 \%$ & $1.63 \%$ & $1.75 \%$ & $1.52 \%$ & $1.40 \%$ & $1.62 \%$ & $1.53 \%$ & $1.63 \%$ & $1.73 \%$ & $1.32 \%$ & $1.49 \%$ & $1.47 \%$ \\
\hline & 90 & $1.49 \%$ & $2.02 \%$ & $2.09 \%$ & $2.69 \%$ & $2.97 \%$ & $1.81 \%$ & $1.82 \%$ & $1.21 \%$ & $1.09 \%$ & $0.95 \%$ & $0.97 \%$ & $0.94 \%$ \\
\hline
\end{tabular}




\begin{tabular}{|c|c|c|c|c|c|c|c|c|c|c|c|c|c|}
\hline & HS & 2008 & 2009 & 2010 & 2011 & 2012 & 2013 & 2014 & 2015 & 2016 & 2017 & 2018 & 2019 \\
\hline \multirow{4}{*}{$\begin{array}{l}\frac{\pi}{\overline{0}} \\
\text { ㅁ } \\
\text { 을 }\end{array}$} & 87 & $.08 \%$ & $03 \%$ & $06 \%$ & $13 \%$ & $.10 \%$ & $0.13 \%$ & $0.14 \%$ & $0.13 \%$ & $0.12 \%$ & $0.16 \%$ & $0.24 \%$ & $0.25 \%$ \\
\hline & 84 & $0.02 \%$ & $0.01 \%$ & $0.02 \%$ & $0.03 \%$ & $0.05 \%$ & $0.02 \%$ & $0.02 \%$ & $0.01 \%$ & $0.01 \%$ & $02 \%$ & $.03 \%$ & $0.08 \%$ \\
\hline & 85 & $0.00 \%$ & $0.02 \%$ & $0.00 \%$ & $0.01 \%$ & $0.00 \%$ & $0.00 \%$ & $0.00 \%$ & $0.00 \%$ & $0.00 \%$ & $0.00 \%$ & $00 \%$ & $0.00 \%$ \\
\hline & 90 & 10 & 100 & 10 & 0 & 10 & $1 \%$ & $\%$ & $\%$ & $\%$ & $0.01 \%$ & $0.03 \%$ & $02 \%$ \\
\hline \multirow{4}{*}{ 금 } & 87 & $0.40 \%$ & $0.35 \%$ & $0.45 \%$ & $0.37 \%$ & $0.40 \%$ & $0.40 \%$ & $0.29 \%$ & $0.29 \%$ & $0.27 \%$ & $0.31 \%$ & $0.26 \%$ & $0.24 \%$ \\
\hline & 84 & $0.05 \%$ & $0.05 \%$ & $0.05 \%$ & $0.05 \%$ & $0.06 \%$ & $0.06 \%$ & $0.05 \%$ & $0.04 \%$ & $0.06 \%$ & $0.04 \%$ & $0.04 \%$ & $0.05 \%$ \\
\hline & 85 & $0.02 \%$ & $2 \%$ & $10 \%$ & $001 \%$ & 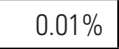 & $0.01 \%$ & $0.01 \%$ & $0.02 \%$ & $0.01 \%$ & $\%$ & $0.01 \%$ & $0.01 \%$ \\
\hline & 90 & $0.06 \%$ & $0.05 \%$ & $0.04 \%$ & $0.04 \%$ & $0.04 \%$ & $0.05 \%$ & $0.04 \%$ & $0.05 \%$ & $0.04 \%$ & $0.04 \%$ & $04 \%$ & $0.04 \%$ \\
\hline \multirow{4}{*}{ 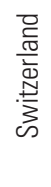 } & 87 & $0.45 \%$ & $0.66 \%$ & $0.52 \%$ & $0.48 \%$ & $0.45 \%$ & $0.32 \%$ & $0.35 \%$ & $0.34 \%$ & $0.34 \%$ & $0.30 \%$ & $0.27 \%$ & $0.28 \%$ \\
\hline & 84 & $0.11 \%$ & $0.13 \%$ & $0.11 \%$ & $0.12 \%$ & $0.10 \%$ & $0.13 \%$ & $0.10 \%$ & $0.10 \%$ & $0.09 \%$ & $0.08 \%$ & $0.10 \%$ & $0.11 \%$ \\
\hline & 85 & $0.17 \%$ & $0.19 \%$ & $0.17 \%$ & $0.18 \%$ & $0.13 \%$ & $0.08 \%$ & $0.10 \%$ & $0.10 \%$ & $0.09 \%$ & $0.08 \%$ & $0.08 \%$ & $0.08 \%$ \\
\hline & 90 & $0.45 \%$ & $0.35 \%$ & $0.25 \%$ & $0.22 \%$ & $0.18 \%$ & $0.19 \%$ & $0.16 \%$ & $0.17 \%$ & $0.19 \%$ & $0.17 \%$ & $0.17 \%$ & $0.18 \%$ \\
\hline
\end{tabular}

Source: ITC statistics. Data organised by HS codes.

In spite of a sluggish growth of Japanese exports to some FTA markets, imports from some specific countries have increased. For example, energy goods such as oil and gas have soared. Figure 5 displays that Indonesia, Australia, Malaysia and Brunei totalled nearly $26 \%$ of all Japanese energy imports in 2007; twelve years later, these countries export $28 \%$ of Japanese energy needs. Middle East is still the principal energy source of Japan, but its sources have been slowly diversified within FTA partners. And as geo-economics goals entail, Japan needs to secure resources for its cutting-edge industries, but most importantly, such energy goods come from nations committed to democracy and to a liberal order that will guarantee Japan a reliable flow of key imports without disturbances of political and ideological nature.

Figure 5. Japanese imports of energy resources 2015 - 2019 (in millions of dollars)

\begin{tabular}{|l|l|l|l|l|l|l|l|l|l|l|l|l|}
\hline Partner & $\mathbf{2 0 0 8}$ & $\mathbf{2 0 0 9}$ & $\mathbf{2 0 1 0}$ & $\mathbf{2 0 1 1}$ & $\mathbf{2 0 1 2}$ & $\mathbf{2 0 1 3}$ & $\mathbf{2 0 1 4}$ & $\mathbf{2 0 1 5}$ & $\mathbf{2 0 1 6}$ & $\mathbf{2 0 1 7}$ & $\mathbf{2 0 1 8}$ & $\mathbf{2 0 1 9}$ \\
\hline $\begin{array}{l}\text { Total imports of } \\
\text { energy }\end{array}$ & 267,787 & 152,489 & 199,139 & 274,652 & 302,532 & 281,585 & 262,106 & 128,287 & 110,878 & 141,218 & 174,569 & 155,618 \\
\hline Australia & 28,765 & 21,751 & 25,819 & 32,157 & 34,676 & 31,368 & 29,704 & 21,426 & 18,838 & 25,659 & 31,456 & 30,580 \\
\hline Indonesia & 19,484 & 10,539 & 13,174 & 17,866 & 17,323 & 15,033 & 12,499 & 7,480 & 5,776 & 6,644 & 6,482 & 5,182 \\
\hline Malaysia & 10,576 & 6,806 & 9,965 & 15,438 & 19,126 & 17,258 & 16,578 & 10,028 & 6,115 & 6,737 & 6,274 & 5,127 \\
\hline Brunei & 4,539 & 3,334 & 4,098 & 5,687 & 5,971 & 4,730 & 3,983 & 2,336 & 1,740 & 1,704 & 2,255 & 2,463 \\
\hline $\begin{array}{l}\text { Imports from FTA } \\
\text { markets }\end{array}$ & 63,365 & 42,430 & 53,056 & 71,147 & 77,097 & 68,389 & 62,764 & 41,270 & 32,469 & 40,744 & 46,468 & 43,354 \\
\hline $\begin{array}{l}\text { As percentage of } \\
\text { total }\end{array}$ & $23.66 \%$ & $27.83 \%$ & $26.64 \%$ & $25.90 \%$ & $25.48 \%$ & $24.29 \%$ & $23.95 \%$ & $32.17 \%$ & $29.28 \%$ & $28.85 \%$ & $26.62 \%$ & $27.86 \%$ \\
\hline
\end{tabular}

Source: ITC statistics.

Besides, Japanese exports have not soared enough to push its trade balance to positive numbers as shown on Figure 6. Partners, from whom Japan obtains energy goods, show the largest trade deficits amongst its FTA trading partners. European partners have displayed a persisting and growing surplus against Japan since 2012. India, Mongolia and Mexico are the only partners Japan get some trade surplus from. Therefore, after each FTA came into effect, no drastic changes in trade has taken place 
and there is no corroboration that Japan's pursuit of bilateral trade agreements has been solely aimed at boosting its exports.

Figure 6. Japanese trade balance per region/country 2008 - 2019 (in millions of dollars)

\begin{tabular}{|l|l|l|l|l|l|l|l|l|l|l|l|l|}
\hline Partner & $\mathbf{2 0 0 8}$ & $\mathbf{2 0 0 9}$ & $\mathbf{2 0 1 0}$ & $\mathbf{2 0 1 1}$ & $\mathbf{2 0 1 2}$ & $\mathbf{2 0 1 3}$ & $\mathbf{2 0 1 4}$ & $\mathbf{2 0 1 5}$ & $\mathbf{2 0 1 6}$ & $\mathbf{2 0 1 7}$ & $\mathbf{2 0 1 8}$ & $\mathbf{2 0 1 9}$ \\
\hline World & 18,878 & 28,734 & 75,715 & $-32,197$ & $-87,411$ & $-118,069$ & $-121,967$ & -695 & 38,008 & 26,240 & $-10,173$ & $-15,222$ \\
\hline ASEAN & $-3,513$ & 2,497 & 11,838 & $-1,910$ & 213 & $-6,822$ & $-11,202$ & $-2,879$ & 3,164 & 2,951 & 2,252 & $-1,560$ \\
\hline Australia & $-30,236$ & $-22,583$ & $-29,199$ & $-38,875$ & $-38,025$ & $-34,056$ & $-33,942$ & $-21,942$ & $-16,328$ & $-22,909$ & $-28,584$ & $-30,964$ \\
\hline Chile & $-5,172$ & $-3,966$ & $-5,034$ & $-7,476$ & $-7,335$ & $-6,321$ & $-6,432$ & $-4,326$ & $-3,781$ & $-4,791$ & $-5,429$ & $-4,683$ \\
\hline EU28 & 40,004 & 13,194 & 20,533 & 15,330 & $-1,840$ & $-6,692$ & $-5,564$ & $-5,257$ & $-1,331$ & -728 & $-3,881$ & $-6,817$ \\
\hline India & 2,639 & 2,610 & 3,344 & 4,255 & 3,590 & 1,521 & 1,143 & 3,245 & 3,514 & 3,509 & 5,508 & 5,613 \\
\hline Mexico & 6,136 & 4,026 & 6,095 & 6,250 & 6,168 & 5,461 & 6,357 & 5,723 & 4,921 & 5,489 & 5,253 & 4,635 \\
\hline Mongolia & 194 & 99 & 137 & 305 & 319 & 281 & 309 & 198 & 260 & 319 & 486 & 560 \\
\hline Peru & $-1,136$ & $-1,090$ & $-1,185$ & $-1,431$ & $-1,766$ & $-1,656$ & $-1,010$ & -449 & -606 & $-1,330$ & $-1,722$ & $-1,777$ \\
\hline $\begin{array}{l}\text { Switzer- } \\
\text { land }\end{array}$ & $-2,083$ & 9 & 978 & 1,383 & $-3,846$ & $-3,984$ & $-4,187$ & $-4,695$ & $-4,524$ & $-2,728$ & $-3,971$ & $-4,078$ \\
\hline
\end{tabular}

Source: ITC statistics.

Thus, Japan's H\&S system follows additional goals. First of all, Japan imposes its preferences on trade, labour division and investment so as to exert its relative economic hegemony. In this manner, the individual rationality of Japanese firms and investors has used FTAs to seek and benefit from the Asian economic integration (KAPUR; SURI, 2014) by linking and integrating cross-border production networks to Japanese interests. Thus, Japan has been seeping its trade and investment preferences to open possibilities to project global power and shape the economic integration process. In this way, the regionalisation of Japanese interests is no longer a strategy of maximising exports alone; instead, it is an instrument of regional and political legitimacy (GIACALONE, 2016, p. 135) that assistances Japan to construct the Asian region - and beyond.

As Japan possesses few instruments to push a regional integration agenda due to the resilient suspicion image from its WWII past, by singing bilateral agreements, Japan's regional and global ambitions are nuanced by the Japanese government preferences to pursue an economic agenda with each country. The host country welcomes FDI in order to create jobs and exports, whereas Japan can assert control over resources, cheap labour and trade strategies. Hence, Japan's decisive autonomy in an interdependent world is secured through creating mutually beneficial relationships of interdependence (BARU, 2013).

In that sense, geo-economics gives Japan a leeway to design and transform the world order. Japan owns relevant hegemonic tools and institutions to do so, such as technological capabilities, capital, government agencies, and it is using them to influence other states. Since geo-economics and competitiveness are joint in an unbreakable unity in nowadays' global order (SCEKIC et al, 2016), Japan is competing with new economic powers in the region such as China and Korea, and as well as other countries that have shown interest to link their own economic growth to the Asia-Pacific region. 
On the one hand, China has proposed the One Belt, One Road initiative as a way to promote its economics interests to other continents through loans, subsidies and other forms of assistance has benefited these countries to consolidate power using Chinese money (YEH, 2016). China also pursued a resources policy towards Australia, reason why strategic security cooperation with Australia became a more explicit issue for the Abe cabinet $(2012$ - 2020) and led to the competition of an FTA with Australia. On the other hand, the Trump administration is responsible for the weakening of US dominance and its lack of strategy is forcing countries to choose between the US and China (SINGH et al, 2019), which has been fuelling confrontation, alliances and the emergence of diverse economic and security initiatives. Amidst uncertainty about the US leadership in Asia and China's emergence, Japan has been forced to engage in some Chinese initiatives and, simultaneously, it has also step up as a leader in supporting US hegemonic order.

Japan, as a regional stakeholder, is actively shaping the regional and global economic integration through an H\&S as it needs to secure its network productions in the Asia-Pacific continent as they are an important form of hegemonic and economic power. Japanese firms through economic engagement policies, such as bilateral FTAs, can make other states become more dependent on Japanese technology and goods (KIM, 2019, p. 157). Thus, the Japanese long-term geo-economics power has its foundations in securing access to vital resources, labour and markets which could contribute to productivity, facilitate industrial development and, ultimately, control more markets globally.

Aside of economic potential gains and securing economic hegemony, FTAs have also been working as a joint declaration of common values. Japan has prioritised the continuation of the current liberal international order from which it has broadly profited. Japan and its agreements with Australia, ASEAN and India, for instance, have included binding commitments to support and endorse free trade, democratic values and regional peace and security. The EU-Japan agreement also represents another way for Japan to take more responsibility in the world, so the chances and potential for closer EU-Japan cooperation are considerable (HILPERT, 2018) in a world of uncertainty and potential conflict. Thence, Japan's H\&S offers a greater possibility to benefit from a global order that will be characterised by a mix of leery cooperation, competition and potential conflict.

Thus, states like Japan expect to obtain gains when they abide by existing rules and make long-term plans based on an understanding of those rules (KIM, 2019, p. 163).

Concluding remarks

Japan has been constructing a H\&S system, attempting to hold the hub position and make the most of each FTA in geo-economic terms. Japan has signed several trade agreements and not all of them have provided more exports. Nonetheless, Japan obtains other benefits of geo-economic nature. Through a H\&S Japan can exert its economic hegemony to secure its geo-economic objectives which encompasses securing raw 
material and energy, safeguarding its regional production networks and getting commitments from its partners to preserve liberal democratic values and free trade. Furthermore, Japan's hub position has enhanced it to set its trade preferences. On the one hand, Japan propels its relative hegemony through securing markets for its high-value added goods so as to get the global economy dependant on them. On the other hand, it has set certain barriers to products due to local political interests.

As bilateralism took stronger roots after the Doha Round failure and the 2008 Great Recession, Japan has pursued an agenda that contributes to form stable relations with other states, in which Japan is playing an important role to design and norm them. In turn, Japan could significantly diminish uncertainty and risks in the long term. In order to guarantee so, Japan needs to participate in writing trade rules under the umbrella of liberal ideals and institutions through trade agreements. This way, Japan understands that the global order will be shaped by meticulous planning and engaging in proactive relations that meliorates Japan's position to boost its economic progress and protect its geo-economic interests regionally and globally.

Bibliography

AKYÜZ, Y.; MILBERG, W. \& WADE, R. Developing Countries and the Collapse of the Doha Round: A Forum. Challenge. [s.l], v. 49, n. 6, p. 6-19, 2006

ANDO, M.; URATA, S. Impacts of Japan's FTAs on Trade: The cases of FTAs with Malaysia, Thailand, and Indonesia. The Research Institute of Economy, Trade and Industry. [s.l], p.1-41, 2015.

BARU, S. India and the World: A Geoeconomics Perspective. Economic and Political Weekly. [s.l], v. 48, n. 6, p. 37-41, 2013.

BENZ, S.; YALCIN, E. Productivity Versus Employment: Quantifying the Economic Effects of an EU-Japan Free Trade Agreement. The World Economy. [s.l], v. 38, n. 6, p. 935-961, 2015.

BERRIOS, R. Peru and Japan: an uneasy relationship. Canadian Association of Latin American and Caribbean Studies. [s.l], v. 30, n. 59, p. 93-129, 2005.

BROWN, D. K.; KIYOTA, K.; STERN, R. M. Computational Analysis of the Menu of US-Japan Trade Policies. World Economy. [s.l], v. 29, n. 6, p. 805-855, 2006.

CALVO, A. ¿Geoeconomía frente a crecimiento económico? El control de las exportaciones de tecnología avanzada en la guerra fría: una aportación desde un país semiperiférico (España). Revista Bibliográfica de Geografía y Ciencias Sociales. [s.l], v. 23, n. 1230, p. 1-36, 2018.

$\mathrm{CAO}, \mathrm{J}$. The consideration of a Hub-and-Spoke status in FTA formation. Bulletin of Economic Research. [s.l], v. 67, n. 4, p. 382-392, 2015.

CHENG-CHWEE, K. Multilateralism in China's ASEAN Policy: Its Evolution, Characteristics, and Aspiration. Contemporary Southeast Asia. [s.l], v. 27, n. 1, p. 102-122, 2005.

CHIRATHIVAT, S.; MALLIKAMAS, S. Thailand's FTA Strategy: Current Development and Future Challenges. ASEAN Economic Bulletin. [s.l], v. 21, n. 1, p. 37-53, 2004.

COWEN, D.; SMITH, N. After Geopolitics? From the Geopolitical Social to Geoeconomics. Antipode. [s.l], v. 41, n. 1, p. 22-48, 2009.

DAS, G. G.; ANDRIAMANANJARA, S. Hub-and-Spokes Free Trade Agreements in the Presence of Technology Spillovers: An Application to the Western Hemisphere. Review of World Economics. [s.l], v. 142, n. 1, p. 33-66, 2006.

DE LA REZA, G. Integración regional vs. integración bilateral: el caso del sistema eje-rayos de México. IMEA-UNILA. [s.l], v. 2, n. 1, p. 1-29, 2014

DE BENEDICTIS, L.; DE SANTIS, R.; VICARELLI, C. Hub-and-Spoke or else? Free trade agreements in the 'enlarged' European Union. The European Journal of Comparative Economics. [s.l], v. 2, p. 2, p. 245-260, 2005. 
DELTAS, G.; DESMET, K.; FACCHINI, G. Hub-and-spoke free trade areas: theory and evidence from Israel. The Canadian Journal of Economics. [s.l], v. 45, n. 3, p. 942-977, 2012.

DINGEMANS, A. East Asia: Chile’s Missed Opportunity? East Asia. [s.l], v. 31, p. 1, p. 67-91, 2014.

FRENKEL, M.; WALTER, B. The EU-Japan Economic Partnership Agreement: Relevance, Content and Policy Implications. Intereconomics. [s.l], v. 52, p. 6, p. 358-363, 2017.

GALLAGHER, K. P. Understanding Developing Country Resistance to the Doha Round. Review of International Political Economy. [s.l], v. 15, n. 1, p. 62-85, 2008.

GAURAV, K.; BHARTI, N. India-Japan CEPA: What RCA Index Reveals for Trade in Services? Foreign Trade Review. [s.l], v. 53, n. 3, p. 189-203, 2018.

GIACALONE, R. Geopolítica y geoeconomía en el proceso globalizador. Bogotá: Ediciones Universidad Cooperativa de Colombia, 2016.

HANS VAN MEIJL, J. F.; VAN TONGEREN, F; EVENETT, S. J. Trade Liberalization in the Doha Development Round. Economic Policy. [s.l], v. 20, n. 42, p. 351-391, 2005.

HATCH, W. Regionalizing the State: Japanese Administrative and Financial Guidance for Asia. Social Science Japan Journal. [s.l], v. 5, n. 2, p. 179-197, 2002.

HATCH, W.; YAMAMURA, K. Asia in Japan's Embrace. Hong Kong: Cambridge University Press, 1996.

HAYAKAWA, K.; MATSUURA, T. FTA Use in Export-Platform FDI: Evidence from Exports to China by Japanese Affiliates in ASEAN. Journal of Southeast Asian Economies. [s.l], v. 34, n. 2, p. 266-282, 2017.

HILPERT, H. The Japan-EU Economic Partnership Agreement-economic potentials and policy perspectives. Asia Europe Journal. [s.l], v. 16, n. 4, p. 439-447, 2018.

HOLSLAG, J. Geoeconomics in a globalized world: the case of China's export policy. Asia Europe Journal. [s.l], v. 14, n. 2, p. 173-184, 2015.

HORAGUCHI, H. H. Economic Analysis of Free Trade Agreements: Spaghetti Bowl Effect and a Paradox of Hub and Spoke Network. Journal of Economic Integration. [s.l], v. 22, n. 3, p. 664-683, 2007.

HUR, J.; ALBA, J. D.; PARK, D. Effects of Hub-and-Spoke Free Trade Agreements on Trade: A Panel Data Analysis. World Development. [s.l], v. 38, n.8, p. 1105-1113, 2010.

JAIN, P. Japan-India Relations: Peaks and Troughs. The Round Table. [s.l], v. 99, n. 409, p. 403-412, 2010.

KAPUR, D.; SURI, M. Geoeconomics Versus Geopolitics: Implications for Asia. In: KAUR, I. N.; SINGH, N. The Oxford Handbook of the Economics of the Pacific Rim. Oxford: Oxford University Press, 2014.

KaWAi, M.; WIGNARAJA, G. Patterns of Free Trade Areas in Asia. Policy Studies. [s.l], n. 65, p. 1-76, 2013.

KAWASHIMA, S. Toward China's "Hub and Spokes" in Southeast Asia? - Diplomacy during the $\mathrm{Hu}$ Jintao and First Xi Jinping Administrations. Asia-Pacific Review. [s.l], v. 24, n. 2, p. 64-90, 2017.

KERBER, V. El sol naciente de Vicente Fox. México y Japón 2000-2006. Foro Internacional. [s.l], v. 48, n. $1 / 2$, p. $352-374,2008$

KIM, D. J. The Perils of Geoeconomics. The Washington Quarterly. [s.l], v. 42, n.1, p. 153-170, 2019.

LEE, J.; PARK, I.; SHIN, K. Proliferating Regional Trade Arrangements: Why and Whither? World Economy. [s.l], v. 31, n. 12, p. 1525-1557, 2008.

LIPSEY, R. Canada at the U.S.-Mexico Free Trade Dance: Wallflower or Partner? Commentary. [s.l], n. 20, p. 2-16, 1990

LLOYD, P. J.; MACLAREN, D. Gains and Losses from Regional Trading Agreements: A Survey. Economic Record. [s.l], v. 80, n. 251, p. 445-467, 2004.

LUONG, D. T. H. Vietnam-Japan Relations in the Context of Building an East Asian Community. Asia-Pacific Review. [s.l], v. 16, n. 1, p. 100-130, 2009.

LUTTWAK, E. From Geopolitics to Geo-Economics: Logic of Conflict, Grammar of Commerce. The National Interest. [s.l], n. 20, p. 17-23, 1990.

MANGER, M. Competition and Bilateralism in Trade Policy: The Case of Japan's Free Trade Agreements. Review of International Political Economy. [s.l], v. 12, n. 5, p. 804-828, 2005. 
MD. KHALID, K. Malaysia’s Foreign Policy under Najib: A Comparison with Mahathir. Asian Survey. [s.l], v. 51, n. 3, p. 429-452, 2011.

MUKUNOKI, H.; TACHI, K. Multilateralism and Hub-and-Spoke Bilateralism. Review of International Economics. [s.l], v. 14, n. 4, p. 658-674, 2006.

PARK, Y. C.; YOO, J. H. More Free Trade Areas: a Korean Perspective. In: SCHOTT, J. J. Free Trade Areas and U.S. Trade Policy. Washington, DC: Institute for International Economics, 1989.

PEKKANEN, S. M.; SOLIS, M.; KATADA, S. N. Trading Gains for Control: International Trade Forums and Japanese Economic Diplomacy. International Studies Quarterly. [s.l], v. 51, n. 4, p. 945-970, 2007.

PURBA, K. Sensitivity and Japan-Indonesia ties. Japan Quarterly. [s.l], v. 48, n. 2, p. 50-55, 2001.

RAHMAN, K. M.; MOLLA, R. I.; MURAD, M. W. Japan-Malaysia Free Trade Agreement: Expectations and Achievements. Journal of Comparative International Management. [s.l], v. 11, n. 1, p. 29-42, 2008

SATO, T. Economic Relations between India and Japan. Eurasian Geography and Economics. [s.l], v. 53, n. 4, p. 457-478, 2012.

SCEKIC, R.; DRASKOVIC, M.; DELIBASIC, M. Neoliberalism in geoeconomics: the case of Southeast Europe. Journal of International Studies. [s.l], v. 9, n. 1, p. 66-75, 2016.

SCHOLVIN, S.; WIGELL, M. Power politics by economic means: Geoeconomics as an analytical approach and foreign policy practice. Comparative Strategy. [s.l], v. 37, n. 1, p. 73-84, 2018.

SEKI, T. A Japan-India front. Far Eastern Economic Review. [s.l], v. 163, n. 21, p. 38, 2000.

SEN, R.; SRIVASTAVA, S. ASEAN's Bilateral Preferential Trade and Economic Cooperation Agreements: Implications for Asian Economic Integration. ASEAN Economic Bulletin. [s.l], v. 26, n. 2, p. 194-214, 2009

SENGUPTA, R. India’s FTA Choices Get More Ambitious. Economic and Political Weekly. [s.l], v. 46, n. 26/27, p. 18-22, 2011.

SINGH, B.; TEO, S.; HO, S.; TSJENG, H. Contending visions of East Asian regional order: insights from the United States, China, Japan, and Indonesia. Asian Affairs: An American Review. [s.l], v. 46, n. 1, p. 19-41, 2019.

SODERBERG, M. Introduction: where is the EU-Japan relationship heading? Japan Forum. [s.l], v. 24, n. 3, p. 249-263, 2012.

SOLIS, M.; KATADA, S. N. The Japan-Mexico FTA: A Cross-Regional Step in the Path towards Asian Regionalism. Pacific Affairs. [s.l], v. 80, n. 2, p. 279-301, 2007.

STUBBS, R. US-Japanese trade relations: the ASEAN dimension. In: MENDL, W.

Japan in South East Asia. Oxford: Routledge, 2001.

TALERNGSRI, P.; VONKHORPORN, P. Trade Policy in Thailand: Pursuing a Dual Track Approach. ASEAN Economic Bulletin. [s.l], v. 22, n. 1, p. 60-74, 2005.

TERADA, T. The Japan- Australia partnership in the era of East Asian Community: can they advance together? In: PANGESTU, M.; SONG, L. Japan's future in East Asia and the Pacific. Canberra: ANU Press, 2007.

VAN DE HAAR, E. Philippine Trade Policy and the Japan-Philippines Economic Partnership Agreement (JPEPA). Contemporary Southeast Asia. [s.l], v. 33, n. 1, p. 113-139, 2011.

WONG, J.; CHAN, S. China-ASEAN Free Trade Agreement: Shaping Future Economic Relations. Asian Survey. [s.l], v. 43, n. 3, p. 507-526, 2003.

WONNACOTT, R. J. Canada's Future in a World of Trade Blocks: A Proposal. Canadian Public Policy. [s.l], v. 1, p. 1, p. $118-130,1975$.

WONNACOTT, R. J. The Economics of Overlapping Free Trade Areas and the Mexican Challenge. Toronto: Canadian-American Committee, 1991.

WONNACOTT, R. J. Trade and Investment in a Hub-and-Spoke System Versus a Free Trade Area. World Economy. [s.l], v. 19, n. 3, p. 237-252, 1996.

WONNACOTT, R. J.; Carsten KOWALCZYK. Hubs and Spokes, and Free Trade in the Americas. NBER Working Paper series. [s.l], n. 4198, 1992.

YEH, E. T. Introduction: The geoeconomics and geopolitics of Chinese development and investment in Asia. Eurasian Geography and Economics. [s.l], v. 57, n. 3, p. 275-285, 2016. 
ei estudos internacionais • Belo Horizonte, ISSN 2317-773X, v. 9, n. 3, (set. 2021), p. 33-52

YILDIZ, H. M. Hub and spoke trade agreements under oligopoly with asymmetric costs. The Journal of International Trade \& Economic Development. [s.l], v. 23, n. 1, p. 97-110, 2014.

YOSHIMATSU, H. Japan's Keidanren and Free Trade Agreements: Societal Interests and Trade Policy. Asian Survey. [s.l], v. 45, n. 2, p. 258-278, 2005.

YOSHIMATSU, H. Japan's quest for free trade agreements constraints from bureaucratic and interest group politics. In: PANGESTU, M. \& SONG, L. Japan's future in East Asia and the Pacific. Canberra: ANU Press, 2007.

YOSHIMATSU, H.; ZILTENER, P. Japan's FTA Strategy toward Highly Developed Countries: Comparing Australia’s and Switzerland's Experiences, 2000-09. Asian Survey. [s.l], v. 50, n. 6, p. 1058-1081, 2010. 